\title{
Why do Europeans Work so Little? *
}

April 14, 2008

Conny Olovsson ${ }^{1}$

Institute for International Economic Studies, Stockholm University, Sweden

\begin{abstract}
Market work per person is roughly 10 percent higher in the U.S. than in Sweden. However, if we include the work carried out in home production, the total amount of work only differs by 1 percent. I set up a model and show that differences in policy - mainly taxes - can account for the discrepancy in both labor supply and home production between Sweden and the U.S. These results are independent of the elasticity of labor supply.
\end{abstract}

JEL classification: D13; H24; J22

Keywords: Labor supply; taxes; home production

\footnotetext{
* Manuscript received in August 2006. Revised and accepted in January 2008.

${ }^{1}$ I am grateful for comments from Kjetil Storesletten, Mats Persson, Jeremy Greenwood, Edward Prescott, Assar Lindbeck, Steven Davis and Per Krusell. Thanks to Annika Andreasson and Christina Lönnblad for editorial assistance. Financial support from Jan Wallander's and Tom Hedelius' Research Foundation is greatly acknowledged.
} 


\section{INTRODUCTION}

International comparisons highlight quite large differences in the extent of market work across countries. Figure 1 displays the average annual work hours in Europe and a group of non-European OECD countries. ${ }^{2}$ According to the data, people living in the nonEuropean group work much more than Europeans. ${ }^{3}$ The difference is 136 hours, or more than five average work weeks per person and year.

$\{$ Figure 1 here $\}$

Theoretical explanations for differences in working hours could, for instance, be crosscountry heterogeneity in preferences, labor taxes, benefits or any other factor influencing the incentives to supply labor. ${ }^{4}$ The aim of this paper is to analyze whether cross-country differences in hours worked could have been generated by heterogeneity in policy. Specifically, the focus is on analyzing how policy affects the way households allocate their time among market work, home production and leisure. ${ }^{5}$

Comparable international data on home production (as well as market work) is a general problem, restricting any study within this field. For three reasons, I will therefore concentrate on Sweden and the U.S. First of all, there exists at least one study with comparable data on home production for Sweden and the U.S. Second, the difference in hours worked between Sweden and the U.S. is roughly the same as the difference between Europe and the non-European group. ${ }^{6}$ However, policy differs substantially between these two countries.

\footnotetext{
${ }^{2}$ The data is for 2002 and is taken from the OECD Labor database. The non-European group consists of Japan, U.S., Australia, Mexico and Canada.

${ }^{3}$ This seems to be robust in the data even though the variance (especially) within the European group is quite large. For instance, if the countries are ranked by working hours, only European countries are placed at the low end and all non-European countries show up at the high end. This is also the case when I use data on average annual hours per employee.

${ }^{4}$ Blanchard (2004) emphasizes the preference argument, Prescott (2004) stresses the role of taxes and Alesina, Glaeser and Sacerdote (2005) argue that labor regulations and union policies are the important explanation.

${ }^{5}$ This is not to say that other explanations are of no importance, but just to try to quantify the importance of differences in policy (for instance tax rates) in accounting for differences in labor supply.

${ }^{6}$ Note, however, that both Swedes and Americans work somewhat more than the average in their respective group.
} 
In fact, tax rates are among the lowest in the U.S., and among the highest in Sweden. ${ }^{7}$ Third and finally, employment/population ratios are of a similar magnitude in the two countries, implying that the difference in hours worked is almost completely generated by differences in hours per worker. ${ }^{8}$

This paper takes into account the fact that households carry out a substantial amount of work outside their workplaces, mainly in home production. ${ }^{9}$ The relation between average annual hours of paid and unpaid work in Sweden and the U.S. is displayed in Fig. 2 below. ${ }^{10,11}$

$\{$ Figure 2 here $\}$

Market work per person is roughly 10 percent (or 120 hours) higher in the U.S. than in Sweden, which is a substantial number. However, figure 2 also displays that average total work only differs by 1 percent. The difference seems to be that Swedes allocate a larger share of their total work effort to home production. ${ }^{12}$

\footnotetext{
${ }^{7}$ Rogerson (2007b) argues that the government can also use its revenue to actually increase the return to market work on the margin.

${ }^{8}$ Even though the model in the paper abstracts from employment status, it makes the comparability of the model and the data clean and straightforward.

${ }^{9}$ Examples of services produced in home production are child care, cleaning, shopping and preparing dinner but also repairs of household goods and vehicles.

${ }^{10}$ The data on market work is for 2002, and is taken from the OECD Labor database. The data on home production in Sweden is based on the estimate that Swedish households on average devote 44 percent of their total working time to domestic work. This relation is quite robust over time (Juster and Stafford (1991), table 1, and Tid för Vardagsliv. Kvinnors och mäns tidsanvändning 1990/91 and 2000/2001, 2003). For the U.S., the data on home production is once more taken from table 1 in Juster and Stafford (1991), wherein it is reported that Americans devote, on average, 39.4 percent of their total working time to domestic work. The data in Juster and Stafford is based on time diaries and represents national population samples. The studies are from 1981 for the U.S., and 1984 for Sweden, but once more, at least for Sweden, the ratio between home and total working hours has been stable over this period. The classifications for the two countries are also claimed to be consistent and to match. The numbers have been weighted by the sex ratio in each population (data from Statistics Sweden and UN, the population database).

${ }^{11}$ Recent research by Burda, Hamermesh and Weil (2006) finds a higher ratio of household production to total work than Juster and Stafford. This is expected, since they consider agents aged between 20-74, and thus include 10 more years of mainly retired individuals. Unfortunately, it is impossible to conclude how much of this difference that comes from the additional age group and how much could potentially be due to changed behavior.

${ }^{12}$ Taken seriously, this data speaks against the preference argument, since leisure is consumed to the same amount in both countries. See also Freeman and Schettkat (2002) who find that German women work as much as American women, but do a larger share of their total work in the household. They also find the same relation between hours of market work and home production for Americans as in this paper, even though they are using different data.
} 
Taxes may be distortionary for households which engage in home production, in at least two important ways. ${ }^{13}$ First, service taxes (VAT) raise the price of market-produced services, making them a less attractive deal. Second, labor taxes distort households' time allocation choice between working in the market and in home production. Specifically, labor taxes reduce the return to market work and increase the return to home production in relative terms. Households subject to labor taxes may therefore start allocating their time to home production, instead of market work, even though their productivity may be lower in the former activity than in the latter. ${ }^{14}$

To analyze whether differences in labor supply could be driven by cross-country heterogeneity in policy, I set up a dynamic general equilibrium model consisting of a large number of households with three arguments in their utility function: consumption goods, services and leisure. Services may be bought in the market, or produced in home production. Households are assumed to be heterogeneous in labor productivity and the problems they face are how to allocate their income between consumption goods and market-produced services, and their time between market work, home production and leisure. ${ }^{15}$

The model is first calibrated to match a number of Swedish features, such as time spent in market work and home production. An important parameter in the model is the elasticity of substitution between market produced and home produced services. This elasticity is estimated and incorporated into the model by ensuring that the share of income that different income groups spend on market services is the same in the model and the Swedish data. Effective tax rates on labor income, consumption and services are estimated on data from the OECD Revenue Statistics database and National Accounts. Second, all policy parameters are changed to U.S. estimates to explore whether the model matches U.S. hours in market work and home production.

It is found that differences in policy - mainly taxes - can account for the different alloca-

\footnotetext{
${ }^{13}$ It is quite well known that taxes may be somewhat more distortionary in the presence of home production; see, for example, Lindbeck (1981), McGrattan et al. (1993), and Davis and Henrekson (2002).

${ }^{14}$ Taxes may also generate income effects, for instance, if the tax system redistributes between individuals and/or the government does not redistribute all proceeds to the individuals.

${ }^{15}$ Naturally, it would be more realistic to consider households with couples, but that complicates the model significantly.
} 
tions of time in Sweden and the U.S. The model predicts GDP per capita to be between 8 and 15 percent higher in the U.S. than in Sweden as a result of different policies. The distortion comes from taxes in general, and labor taxes in particular. I also find the (Frisch-) labor supply elasticity to be of no importance for the results. The elasticity is varied from extremely high to very low values, without affecting the results in any significant way. ${ }^{16}$ The important margin is instead households' decisions on how to allocate their time between home and market hours. The model predicts that Swedish GDP per capita would increase by 25 percent as a result of changing to U.S. tax rates (while holding other policy parameters constant). I also compare how model market hours for different income groups compare to the data, and quantify the effects of policy on different income groups. All income quintiles but the first are better off under U.S. tax rates than under Swedish ones.

These results are stable under two very different assumptions about what the government does with its tax revenues. ${ }^{17}$ Moreover, the fact that consumption of publicly provided child care in Sweden is highly subsidized (and conditional on working), is found to be a quantitatively plausible explanation for Sweden's relatively high level of labor supply among European countries. The model is also consistent with the falling trend in market hours in Sweden since 1960, but clearly overestimates the number of hours worked between 1960 and 1975.

Even though the model does a good job in explaining differences in hours between Sweden and the U.S., it is an open question whether it would also be able to account for the allocation of hours in a broader set of European countries. This is discussed in a separate section at the end of the paper. Other recent related studies analyzing the causes of labor supply are Rogerson (2007a) and Nickell (2004).

\footnotetext{
${ }^{16}$ Prescott (2004) argues that virtually all differences between U.S. labor supply and those of continental Europe are due to differences in tax systems. This explanation has then been criticized by Alesina, Glaeser and Sacerdote (2005), mostly on the grounds that the labor supply elasticities assumed by Prescott are unrealistically high.

${ }^{17}$ In a Separate Appendix, available from the author upon request, I evaluate the sensitivity of the results over a broad range of alternative assumptions, such as different parameter values, the introduction of home capital, capital taxes, alternative service taxes etc, and find that none of these assumptions change the results in a quantitatively important way.
} 


\section{THE MODEL}

\subsection{CONSUMERS}

Consider an economy with a continuum of infinitely lived households. The instantaneous utility for household $i$ in period $t$ is specified by

$$
u\left(c_{i t}, s_{i t}, l_{i t}\right)=\frac{\left(c_{i t}^{\eta} s_{i t}^{1-\eta}\right)^{1-\gamma}}{1-\gamma}+\varphi \frac{l_{i t}^{1-\mu}}{1-\mu}
$$

where $c_{i t}$ is consumption goods, $s_{i t}$ services and $l_{i t}$ leisure. Households can either buy services in the market or produce them in home production. For simplicity, the production function for services is assumed to be linear in efficiency hours $\epsilon_{n} h_{i t, n}$ of work.

$$
F^{S}\left(\epsilon_{n} h_{i t, n}\right)=s_{i t, n}=\epsilon_{n} h_{i t, n}
$$

where $h_{i t, n}$ is the time household $i$ devotes to home production and $\epsilon_{n}$ the productivity in that activity. ${ }^{18}$ I assume all households to have the same constant productivity in home production, i.e. $\epsilon_{n}=\bar{\epsilon}_{n} \cdot{ }^{19}$ Services are thus an aggregate of market-produced services $s_{i t, m}$, and home-produced services $s_{i t, n}$ :

$$
s_{i t}=\left[a\left(s_{i t, m}\right)^{b}+(1-a)\left(s_{i t, n}\right)^{b}\right]^{\frac{1}{b}} .
$$

\footnotetext{
${ }^{18}$ The assumption of no capital in the home sector is made for simplicity. However, the results are robust to the alternative specification that (2) is instead a Cobb-Douglas in home capital and hours.

${ }^{19} \mathrm{It}$ is assumed that agents have a higher productivity in market work than in home production (on average). This and the assumption of the zero correlation between individual productivities are based on the fact that people tend to be more specialized in the former activity than in the latter. In a Separate Appendix, alternative assumptions for $\epsilon_{n}$ are considered. Specifically, I allow individual home productivity to be correlated with market productivity.
} 
Households supply labor to the labor market, consisting of the goods market and the service sector. ${ }^{20}$ I abstract from earnings uncertainty by assuming each household to be endowed with a constant, but heterogenous level of labor productivity $\epsilon_{i}=e^{\xi_{i}}$, where $\xi$ is a permanent component assumed to be normally distributed with mean zero and variance $\sigma_{\xi}^{2}$. Each household has one unit of productive time per week, which must be divided between labor, home production and leisure

$$
h_{i t}+h_{i t, n}+l_{i t}=1 \text {. }
$$

Denoting taxes on consumption, services and labor income by $\tau_{t}^{c}, \tau_{t}^{s}$ and $\tau_{t}^{h}$, respectively, the budget constraint of household $i$ is

$$
\left(1+\tau_{t}^{c}\right) c_{i t}+\left(1+\tau_{t}^{s}\right) p_{t} s_{i t, m}+a_{i t+1}=\epsilon_{i} w_{t} h_{i t}\left(1-\tau_{t}^{h}\right)+\left(1+r_{t}\right) a_{i t}+\psi_{t}
$$

where $a_{i t+1}$ are the assets the household chooses to hold for the next period, $p_{t}$ the market price of services, $r_{t}$ the interest rate, $w_{t}$ the wage rate in period $t$ and $\psi_{t}$ a transfer from the government. ${ }^{21}$ Finally, households are not allowed to short-sell any assets

$$
a_{i t+1} \geq 0, h_{i t} \geq 0, s_{i t, m} \geq 0, h_{i t, n} \geq 0
$$

The households' maximization problem is to maximize their expected life-time utility,

\footnotetext{
${ }^{20}$ It is of no importance for the aggregates how agents are allocated between the two sectors as long as both markets clear.

${ }^{21}$ Capital taxes are abstracted from in the benchmark setting. However, introducing capital taxes actually slightly improves the results (see the Separate Appendix).
} 


$$
U_{0}=\sum_{t=0}^{\infty} \beta^{t} u\left(c_{i t}, s_{i t}, l_{i t}\right),
$$

subject to (4), (5) and (6), where $\beta$ is the subjective discount factor.

Finally, let $\chi(a, \epsilon)$ be the measure of households, and normalize the mass of households to unity.

\section{$2.2 \quad$ FIRMS}

The production side of the economy consists of goods and services. There is no aggregate uncertainty in the economy. Since the analysis mostly focuses on steady states, time subscripts are suppressed from now on. Let $K$ denote aggregate capital stock, and $H_{g}$ the

aggregate labor supply in efficiency units in the goods market, i.e. $H_{g}=\int \epsilon h_{g}(a, \epsilon) d \chi$. The aggregate production of consumption goods is assumed to be given by

$$
F^{g}\left(K, H_{g}\right)=K^{\alpha} H_{g}^{1-\alpha}
$$

Moreover, let $H_{s}$ be aggregate labor supply in efficiency units in the service sector, i.e. $H_{s}=\int \epsilon h_{s}(a, \epsilon) d \chi$. According to (2), the aggregate production of market-produced services is then given by $H_{s}$. Firms maximize their profit, while taking prices as given.

\subsection{THE GOVERNMENT}

Rogerson (2007b) argues that government revenues may be returned in ways that make the return to market work higher, lower or unaffected on the margin. ${ }^{22}$ Since this is a potentially important issue, I consider two very different ways of handling revenues. The first simply assumes that the government consumes a share $G$, and then distributes the

\footnotetext{
${ }^{22}$ See also Lindbeck (1982) and Ragan (2005).
} 
remaining proceeds back to all agents lump-sum. This is a somewhat simplistic view and it does not really address the issue of how different parts of government consumption might affect the return to market work on the margin. ${ }^{23}$ The second approach, on the contrary, assumes that all proceeds are redistributed back lump-sum to all agents, but also takes into account that publicly provided child care in Sweden is largely subsidized. The subsidy on day care affects the relative price between working at home, and working in the market in favor of the latter alternative, since it becomes less costly to supply labor. In addition, receiving the subsidy is conditional on working. Consequently, the subsidy increases the return to market work on the margin. ${ }^{24}$

I incorporate this into the model by introducing a subsidy to labor income, $\tau^{n} \cdot{ }^{25}$ The government is required to balance its budget in each period, which yields the following budget constraint: ${ }^{26}$

$$
\left(\tau^{h}-\tau^{n}\right) w H+\tau^{c} C+\tau^{s} p S_{m}-G=\Psi
$$

where $C=\int c(a, \epsilon) d \chi$, is aggregate consumption of goods, $S_{m}=\int s_{m}(a, \epsilon) d \chi$, aggregate demand for market-produced services, $H_{n}=\int h_{n}(a, \epsilon) d \chi$, aggregate hours of home production and $\Psi$ is the transfer in a given period.

\section{EQUILIBRIUM}

Denote the vector of taxes by $\Gamma=\left[\tau^{c}, \tau^{s}, \tau^{h}, \tau^{n}\right]$. An equilibrium for this economy is then given by (i) decision rules for agents' asset holdings $\widehat{a}_{i, t+1}=\widehat{a}^{\prime}\left(a_{i}, \epsilon_{i} ; p, r, w, \Gamma, \psi\right)$, marketproduced services $s_{m}=s\left(a_{i}, \epsilon_{i} ; p, r, w, \Gamma, \psi\right)$, hours of market work $h=h\left(a_{i}, \epsilon_{i} ; p, r, w, \Gamma, \psi\right)$

\footnotetext{
${ }^{23}$ However, it produces income effects.

${ }^{24}$ Naturally, there might be other components of government consumption that could potentially affect the marginal return to market work, such as elderly care. In this paper, such other components are abstracted from.

${ }^{25}$ Alternatively, the government could instead give some of the revenue back directly in the form of a good that constitutes a close substitute to the home-produced good. In fact, that approach seems to generate very similar results.

${ }^{26}$ This is a natural benchmark, since the analysis mainly concentrates on steady-state comparisons.
} 
and hours in home production $h_{n}=h\left(a_{i}, \epsilon_{i} ; p, r, w, \Gamma, \psi\right)$; (ii) aggregate values for asset holdings $A(p, r, w, \Gamma, \psi)=\int \widehat{a}(a, \epsilon) d \chi$, for market-produced services $S_{m}(p, r, w, \Gamma, \psi)=$ $\int s(a, \epsilon) d \chi$, and for labor supply to the service sector $H_{s}(p, r, w, \Gamma, \psi)=\int \epsilon h_{s}(a, \epsilon) d \chi$ and the goods sector $H_{g}(p, r, w, \Gamma, \psi)=\int \epsilon h_{g}(a, \epsilon) d \chi$, such that the following conditions hold:

- The decision rules solve the households' maximization problem

- Employment is positive in both sectors, i.e.,

$$
w_{s}=w_{g}=w .
$$

- Prices are given by

$$
r=F_{K}\left(K, H_{g}\right)-\delta, \quad w_{t, g}=F_{H_{g}}\left(K, H_{g}\right), \quad p=\frac{F_{h}^{g}}{F_{h}^{s}}
$$

where $p=F_{h}^{g} / F_{h}^{s}$ is derived from the fact that profits in the service sector must be zero. ${ }^{27}$

- Tax revenues equal government expenses, i.e. equation (8) holds

- The aggregate supply of savings is equal to firms' demand for capital,

$$
A(p, r, w, \Gamma, \Psi)=K(p, r, w, \Gamma, \Psi) .
$$

\footnotetext{
${ }^{27}$ Specifically, $p$ is - in terms of foregone consumption goods, relative to the amount of services produced - the cost of using a marginal unit of labor for production of services instead of consumption goods. The price of consumption goods is normalized to 1 . Alternative technologies yield different prices.
} 
- The demand for services equals the supply

$$
S_{m}(p, r, w, \Gamma, \Psi)=H_{S}(p, r, w, \Gamma, \Psi)
$$

\section{Calibration}

The first goal is now to calibrate the model to Sweden. I here discuss the benchmark calibration, but the sensitivity of the results is evaluated in a Separate Appendix where a broad range of alternative parameter values are considered. On the production side, standard values are used for the parameters, namely $\alpha=0.3 ; \delta=0.08$. The preference parameters are $\beta, \gamma, \mu, \varphi, \eta, a$ and $b$. The discount factor $\beta$ is set to 0.96 in order to generate an interest rate at around 4 percent. ${ }^{28}$ To get some additional intuition, assume that $\gamma=\mu=1$, and $b=0$. Recall that $b$ determines a household's choice between marketproduced and home-produced services, since $(1 /(1-b)$ is the elasticity of substitution between these two objects. ${ }^{29}$ The first-order conditions are then given by: ${ }^{30}$

$$
\frac{c_{i}}{s_{i, m}}=\frac{\eta}{a(1-\eta)} p \frac{\left(1+\tau^{s}\right)}{\left(1+\tau^{c}\right)}
$$

$$
\frac{h_{i, n}}{l_{i}}=\frac{(1-\eta)(1-a)}{\varphi} .
$$

\footnotetext{
${ }^{28}$ This generates a capital-output ratio of 2.15 in the Swedish economy with $G>0$, and 1.98 with $G=0$, which is close to the value of 2 as reported in De Nardi (2002). The results are not sensitive to changes in the capital-output ratio.

${ }^{29}$ For example if $b=1$, then $s_{m}$ and $s_{n}$ are perfect substitutes and, if $b=0$, then $s_{i}$ is a Cobb-Douglas function of $s_{m}$ and $s_{n}$.

${ }^{30}$ The equations (14)-(15) are very similar when $b=1$ (i.e., when the two types of services are perfect substitutes), with the only difference that $a$ does not emerge in any of the first-order conditions, since agents then only consume one type of service.
} 


$$
\frac{c_{i}}{l_{i}}=\frac{\eta \epsilon_{i}}{\varphi} w \frac{\left(1-\tau^{h}\right)}{\left(1+\tau^{c}\right)}
$$

Note, however, that the first-order conditions are much more complex whenever $0<b<1$. Equation (15) is just a standard intra-temporal Euler equation (except for parameter $\eta$ ). Equation (14) shows that the ratio of home hours to leisure is decreasing in $a, \eta$ and $\varphi$. Even though the ratio does not directly depend on taxes, the amount of leisure consumed does. Equation (13), finally, governs the relation between consumption goods and market services. Clearly, this margin is affected by the tax rates on services and consumption.

Parameters $a, \eta$ and $\varphi$ thus jointly determine the ratio of consumption goods to market produced services, hours worked in home production (relative to leisure) and, implicitly, hours spent in leisure (or, equivalently, total work time). Hence, these parameters are calibrated to match the corresponding Swedish averages. First, there is an average ratio of consumption goods to market produced services of $3.15 .{ }^{31}$ Second, households on average spend 23.88 hours per week in market work and third, 18.76 hours per week in home production (see table 1 below). ${ }^{32}$

The intertemporal elasticity of substitution for consumption is set to 0.5 , which implies $\gamma=2 .{ }^{33}$ Parameter $\mu$ determines the intertemporal (Frisch) elasticity of substitution for labor. ${ }^{34}$ Rupert, Rogerson and Wright (2000) use different data sets for men to estimate this elasticity in a model with home production (very similar in structure to the one in this paper) and find values around $0.3 .^{35}$ Since estimates for women are generally higher, I set $\mu$ to 5 , implying a Frisch elasticity around 0.48. Maybe surprisingly, the results are

\footnotetext{
${ }^{31}$ See SOU (1997), table 3.16. I have excluded house rents from private consumption.

${ }^{32}$ The relationship between market work and home production is very stable in the three existing studies: Swedes devote approximately 56 percent of their total working time to market work and 44 percent to home production.

${ }^{33}$ This is in the middle of the empirical estimates. See Browning (1999).

${ }^{34}$ The Frisch elasticity of labor supply is defined as the elasticity of labor supply with respect to the wage keeping the marginal utility of consumption constant. In the model, this elasticity is given by $\frac{l_{i t}}{h_{i t}} \frac{1}{\mu}$. Note that there are no shocks to wages in the model, so that the interpretation of the Frisch elasticity is somewhat unclear

${ }^{35}$ Estimates of the Frisch elasticity in models without home production are generally in the interval 0-0.3 for men, with most of them in the lower range of this interval. See Browning et al (1999) for a survey.
} 
robust to large changes in this parameter. ${ }^{36}$

Parameter $b$ is set to match cross-sectional properties. Note that when the two types of services are perfect substitutes $(b=1)$, the low-productivity households satisfy their total demand for services from home production, whereas the high-productivity households exclusively choose market services. As $b$ is increased, low producivity households increase their demand for market services, and the high productivity households start engaging in home production. This is illustrated in figure 3.

$\{$ Figure 3 here $\}$

To calibrate $b$, I first estimate (using a simple OLS-regression) how the ratio $\frac{s_{i m}}{y_{i}}$ varies with disposable income in the data. ${ }^{37}$ A similar regression is then run on the model, and $b$ is set so that the slope of the function estimated on the model is the same as the function estimated on the data. ${ }^{38}$ The implied elasticity is $1.33(b=0.25)$ which is slightly lower, but not inconsistent, with the findings in previous research. ${ }^{39,40}$ Finally, note that $\bar{\epsilon}_{n}$ does not show up in any of the first-order conditions (13)-(15). Hence, hours and GDP are unaffected by this parameter. I set $\bar{\epsilon}_{n}=0.46 E\left[\epsilon_{i t}\right] .{ }^{41}$

I now turn to the policy parameters. Average effective tax rates (AETRs) on labor, consumption and market produced services for Sweden and the U.S. are estimated from

\footnotetext{
${ }^{36}$ See the Appendix.

${ }^{37}$ The data is very detailed and divided into around 30 different categories, which makes identification of the market produced services possible. House rents are once more included.

${ }^{38}$ The regression on the model is significant at the one-percent level, whereas the regression on the data is significant at the five-percent level. The data is taken from Utgiftsbarometern 2001 (2002), table 6, and is denoted for deciles. Note that total household expenditures, $c_{i}+p s_{i, m}$ must equal disposable income, $y_{i}$. Since $C / S_{m}$ is already calibrated to match the data, the mean fraction will also match the data.

${ }^{39}$ McGrattan et al. (1993) use aggregate time series for a business cycle model with home production to assess the elasticity. Rupert et al. (1995) use micro data that includes information on time spent in home production.

${ }^{40}$ The elasticity is higher and closer to McGrattan et al. (1993) and Rupert et al. (1995) when home capital is introduced (see the Appendix). Naturally, it is also possible that elasticity is actually lower in Sweden, for instance, because of different regulations (see Jacobsen and Kooreman, 2005). In this paper, however, preferences are assumed to be the same in the two countries.

${ }^{41}$ In the model, $E\left[\epsilon_{i t}\right]=1.0743$. Naturally, the fact that $\epsilon_{n}$ does not show up in the first-order conditions could be a special case for $b=0$. However, it is straightforward to verify that this is true also when $b=1$. I also verify numerically that cross country differences in hours worked are unaffected by $\epsilon_{n}$. The estimate for $\epsilon_{n}$ is set so that the value of Swedish home production is between 25 to 30 percent of measured GDP (see Hultkrantz and Johansson, 2003).
} 
National Accounts data and Revenue Statistics (see the Appendix for details). For Sweden, these tax rates are $\tau^{h}=0.4601 ; \tau^{c}=\tau^{s}=0.20 .{ }^{42}$ Parameter $\sigma_{\xi}^{2}$, determining the degree of wage dispersion, is calibrated with estimates from Flodén and Lindé (2001). ${ }^{43}$ For Sweden, they find that $\sigma_{\xi}^{2}=0.143 .{ }^{44}$

Once the model is calibrated to Sweden, the question of whether differences in labor supply between Sweden and the U.S. could have been generated by cross-country heterogeneity in policy can be addressed. This is done by re-calibrating all policy parameters so that they are consistent with U.S. data. At the same time, preference and production parameters are kept constant.

U.S. taxes are estimated to be $\tau^{h}=0.2679 ; \tau^{c}=0.0805 ; \tau^{s}=0$, and the estimate of $\sigma_{\xi}^{2}$ is once more taken from Flodén and Lindé (2001) and set to $\sigma_{\xi}^{2}=0.375 .{ }^{45}$ Finally, some assumptions regarding the wealth distribution are needed. I assume the distribution of wealth to be the same in both countries, and the fraction of wealth held by the respective quintile to be $\left[\begin{array}{lllll}0 & .01 & .08 & .19 & .72\end{array}\right] .{ }^{46}$

The allocations of hours in Sweden and the U.S. are summarized in table $1 .^{47}$

\{Table 1 here $\}$

\footnotetext{
${ }^{42}$ Ideally, I would like to allow for progressive tax rates but unfortunately, there does not seem to be any fully satisfying method for estimating progressive tax rates. Generally, it is not clear that a specific aggregation of incomes based on tax-bracket weights, or marginal tax rates which apply to particular individuals in a household survey, are equivalent to the aggregate tax rates that affect macroeconomic variables as measured in national accounts. However, some results for progressive taxes are reported in a Separate Appendix.

${ }^{43}$ I have verified their estimate for the U.S., by directly estimating the wage variance from the PSID data for 1992. The Swedish data is unfortunately not public so I have not been able to verify their estimate for Sweden.

${ }^{44}$ I thus view wage dispersion as a policy instrument. Admittedly, this is a somewhat crude way of capturing the ambition of some unions in Europe to compress wages.

${ }^{45}$ In most states, sales taxes on services are zero (see Isaacson and Bertoni, 2000).

${ }^{46}$ Domeij and Klein (1998) document the distribution of wealth to be about as unequal in Sweden as in the U.S. (in the sense that the Gini coefficient is roughly the same). The model distribution is slightly adjusted to make it consistent with the short-selling constraint, i.e. there are no households with negative wealth.

${ }^{47}$ The data is the same as in figure.2, except that the annual numbers are divided by 5200 (52 weeks times 100 productive hours per week), and then multiplied by 100 to obtain the percentage terms. In this way, the numbers both express hours in percent and hours per week. Data on PPP adjusted GDP from the OECD Statistical Database. GDP per capita means GDP per person aged 20-64.
} 
As pointed out above, the robustness of the results is evaluated in a Separate Appendix where I consider different parameter values, tax rates on services and capital, progressive taxes, alternative technologies, home capital and assumptions about individual productivity.

\section{The Tax Revenues}

Two cases of revenue treatment are considered. In the first case, the government is assumed to consume a share $G$, and distribute the remaining proceeds back to all agents lumpsum. ${ }^{48}$ Government consumption in Sweden is set to 28.1 percent of GDP, as reported in European Economy (2004), table 17, whereas U.S. government consumption is set to 15.2 percent of GDP (the Economic Report of the President 2004, table B-20).

In the second case, all proceeds are redistributed lump-sum to all agents. However, the fact that publicly provided child care in Sweden is subsidized is also taken into account. ${ }^{49}$ The rules in Sweden are basically such that day care is only available for households that are working and households that choose to take care of their kids at home cannot collect the subsidy. Thus, on the margin, the subsidy increases the return to market work. The total cost of the subsidy for the Swedish government amounts to roughly 8 percent of total consumption. I incorporate this into the model by letting a share of the government's tax revenues finance the subsidy on market work. As in the data, the total cost of the subsidy is set to 8 percent of total consumption (the exact procedure used to estimate the subsidy is described in the Appendix). The U.S. subsidy is set to zero. Even though some child care subsidies are available, they are primarily for low-income families and funds are severely limited..$^{50}$

\footnotetext{
${ }^{48}$ Transfers are given back as transfer payments and/or in-kind.

${ }^{49}$ The statutory subsidy rate on publicly provided child care in Sweden is 90 percent of the cost.

${ }^{50}$ According to Giannarelli et al. (2003), at most 12 percent of the eligible children who need help are getting assistance from either the government or another organization.
} 


\section{$6 \quad$ Steady State Results}

\subsection{Changing All Policy Parameters}

In this section, the model is compared to the data to see whether heterogeneity in policy can explain the different allocations of hours in Sweden and the U.S. As a starting point, all policy parameters are changed simultaneously, but their separate effects are analyzed in the subsequent sections. The column marked $G>0$ refers to the case with positive government consumption, whereas that marked $G=0$ shows the case where all proceeds are redistributed back to the agents. The results are presented in table $2 .{ }^{51}$

\{Table 2 here\}

The model matches time spent, both in market work and home production very well in both cases. It also gets both the direction and the magnitude of labor supply to be of the right order. The first economy $(G>0)$ is somewhat better in replicating market hours, and somewhat less successful in replicating home hours than the second economy $(G=0)$. Overall, both predictions of the models are close to the data. In fact, market work in the model with $G>0$ only exceeds that in the U.S. by 2.21 percent, whereas the estimate for home production undershoots the data by 6.04 percent, corresponding to approximately 49 hours/year, or roughly 8 minutes/day.

The model quantifies the output loss of the Swedish policy to between 8 and 15 percent, (i.e., GDP per capita is 8 to 15 percent higher in the U.S. than in Sweden). However, even though the model can explain a fraction of the difference in GDP per capita between Sweden and the U.S., it still leaves a large share unexplained. As can be seen in table 3, the two cases have very different implications for the aggregates.

\footnotetext{
${ }^{51} \mathrm{GDP} /$ capita adjusted is defined as GDP/capita plus the amount of home-produced services evaluated at the market price.
} 
\{Table 3 here $\}$

The first model $(G>0)$ predicts a small difference in capital stocks, and the major part of the GDP per capita difference to come from the service sector, whereas the second instead predicts both the capital stock and the level of consumption goods to be much higher in the U.S. In that model, only four percent of the total 15 percent GDP/capita difference come from the service sector.

Table 4 shows hours worked in the market as a share of total work hours for different income quintiles. ${ }^{52}$

\{Table 4 here\}

Even though the data is not matched exactly, the model predictions are fairly close to the data. The ratios are increasing in income as in the data (except for the last quintile for Sweden, when $G>0$ ), which is encouraging since this dimension was never part of the calibration process.

\subsection{Analyzing Policy Instruments Separately}

In the above section, all policy parameters are changed simultaneously. Here, they are instead analyzed separately to evaluate the individual importance of each policy. Since the results were found to be similar under the two assumptions of government consumption, the analysis will exclusively concentrate on the case with positive government consumption from now on. The result is shown in table 5. The first column is the benchmark case of Sweden. The second column only shows the effect of changing government consumption, i.e., 20.18 would be the number of hours worked in the market if Sweden had the same

\footnotetext{
${ }^{52}$ Income is disposable income per adult in the household. The Swedish data is from Statistics Sweden and the U.S. data is taken from the American Time Use Study (ATUS) for the year 2003. Specifically, the ATUS-CPS contains data on income.
} 
level of government consumption as the U.S., while keeping all other policy parameters at their Swedish levels. Consequently, the third column shows the effect of changing wage dispersion only and the fourth the effect of changing taxes only.

\section{\{Table 5 here\}}

Table 5 shows that taxes have a large impact on the allocation of work hours. This distortion is also associated with a considerable output loss: GDP per capita is 25 percent higher in the economy with U.S. than with Swedish taxes. This is a substantial number, almost equal to 9000 dollars/person (denominated in 2004 prices).

Changing government spending decreases both market work and GDP per capita. This immediately follows from the government budget constraint (8), since reducing government spending, while keeping taxes fixed, implies higher transfers. The implication is a weaker incentive to work - mainly for low productivity households. The effect on labor supply is large, implying that the results are sensitive with respect to assumptions about government consumption.

Changing the wage dispersion decreases market work and significantly increases home production, which indicates that heterogeneity may be an important factor in explaining cross-country differences in hours. However, no major output loss is associated with such a switch. The reason is that a higher dispersion enhances the incentive to supply labor for high-productivity households (they are facing a higher return to labor), while it is reduced for low-productivity households (who are facing a lower return to labor). The net effect is negative, but the drop in GDP per capita stemming from the lower work effort of low-productivity households is almost completely offset by the increased work effort of high-productivity households. ${ }^{53}$

\footnotetext{
${ }^{53}$ Basically, the labor supply of the poor falls dramatically (by $33 \%$ ). The incentive for low productivity households to work is very weak under this regime, which features high transfers, high taxes and low wages.
} 


\subsection{Analyzing Taxes Separately}

To evaluate the quantitative importance of each of the different taxes, their separate effects are shown in table 6. Once more, the second column shows the effect of changing labor taxes only and so on. Both wage dispersion and government consumption are set to Swedish data.

\{Table 6 here\}

What is striking from table 6 is that labor taxes really distort the choice between working in the market and at home. The output loss from labor taxes is substantial: GDP per capita is 18 percent higher with U.S. than with Swedish labor taxes.

The modest distortion associated with service taxes is somewhat surprising. Service taxes would potentially have a large influence on the choice between buying and producing services. The mild distortion in the model is due to the low elasticity of substitution between home and market produced services.

Finally, consider the welfare effects of having U.S. taxes in Sweden for different income groups, which is shown in table $7 .{ }^{54}$ The mean welfare gain is four and five percent, respectively, but the welfare effects are much larger for individual income groups, particularly for the top and bottom quintiles. Once more, the two economies give somewhat different predictions.

\{Table 7 here\}

\footnotetext{
${ }^{54}$ Specifically, it shows the compensating variation $(\mathrm{CV})$ for each quintile, i.e., the amount by which consumption must be increased in the benchmark economy for agents to be indifferent between this and the alternative.
} 


\section{Transition Analysis}

In this section, I analyze whether policy can account for the trend in hours worked over time. More specifically, I look at Sweden during the period 1960-2002. Also in this case do I consider the case with positive government consumption. ${ }^{55}$

The model economy is assumed to start out in a steady state, calibrated with taxes and government consumption set to their 1960 values. Taxes and government consumption are then changed according to their observed values for each year, for the period 19602002. ${ }^{56}$ From 2002 and onwards, taxes and government consumption are held constant at their 2002 values. All preference and production parameters are the same as in the above analysis. Households have complete information about the transition path. The result is presented in figure 4 below. ${ }^{57}$ The tax wedge is defined as $1-\frac{\left(1-\tau^{h}\right)}{\left(1+\tau^{c}\right)}$.

$\{$ Figure 4 here $\}$

The model is consistent with the falling trend in hours worked since 1960. Both in the model and in the data does the largest reduction occur from 1960 until around 1980. This is also the period when taxes increased the most. After 1981, the trends for both taxes and actual hours worked seem to be almost flat, which is also what the model predicts for hours worked.

The correlation between hours worked in the data and the tax wedge is -0.53 , and the correlation between hours worked in the data and the model is 0.45. Even though the model seems to be consistent with long-run behavior, it cannot really explain the short-

\footnotetext{
${ }^{55}$ The necessary variables for estimating the efficient implicit tax rate on home production are only available for a limited number of years.

${ }^{56}$ Data on government consumption is taken from Statistics Sweden (SCB at www.scb.se). Data on hours worked, population and employment 20-64 is from the OECD Labor Database. Average efficient tax rates on consumption goods and services are estimated as described in the Appendix. Unfortunately, several variables needed to estimate AETRs on labor are currently unavailable prior to 1993. Therefore, I instead use statutory income and payroll tax rates. Income taxes are taken from Skattestatistisk årsbok 2002 (2002), and payroll taxes are taken from Skattebetalarnas Förening at www.skattebetalarnas.se.

${ }^{57}$ Data on average hours worked, employment and population for people between 20 and 64 was once more taken from the OECD Labor Database.
} 
term movements observed in the data, which is not very surprising. The model obviously abstracts from a number of potentially important features like business cycles. The discrepancy between 1985 and 1990 is, for example, most likely driven by the international boom in this period.

However, the model clearly overestimates the number of hours worked between 1960 and 1975. It is not really obvious how to reduce this gap. I have made some experiments with productivity growth, but that does not seem to improve the fit. Several important factors not captured by the model may have changed over this period. One of the more important factors is probably the steadily increasing trend in female labor supply. The low number of hours worked at the beginning of the period is actually due to a low employment/population ratio. A richer model with couples might do a better job in accounting for the data. I leave this to future research.

\section{Discussion}

This paper started out by claiming that Swedes devote a larger share of their total work hours to home production than Americans. The question raised was then whether this can be explained by differences in policy, i.e. mainly taxes. I find that, even with a low labor supply elasticity, it can. These results are stable and robust. In fact, in a Separate Appendix (available from the author upon request), I evaluate the sensitivity of the results with respect to a broad range of alternative assumptions, such as different parameter values, the introduction of home capital, capital taxes, alternative service taxes etc, and find that none of these assumptions change the results in a quantitatively important way.

However, whether the model would also be able to account for hours worked in a broader set of European countries is an open question. First, even though total work is of the same magnitude in the two countries considered here, Burda, Hamermesh and Weil (2006) argue that this is not true in general. Second, there are several other potential explanations for the observed differences. Alesina, Glaeser and Sacerdote (2005) instead argue that the 
number of market hours is lower in Europe because the unions have been very influential in the process of regulating the labor market (such as the 35-hour week in France). According to them, a heavily unionized economy is more likely to experience a decrease in hours worked when hit by a negative shock than a non-unionized economy. They also find a quite strong correlation between hours worked and the percentage of the population that is covered by collective bargaining (but also between marginal tax rates and unionization). Clearly, this issue is relevant for the two countries considered here, since Sweden (by any measure) is highly unionized, whereas the U.S. is not. It would be interesting to incorporate unions in the model in this paper and try to quantify the combined effects of taxes and unions on the allocation of time. This might instead raise the question of why Europeans are actually working as much as they do (in the market), given the taxes and regulations they face.

\section{Appendix}

\section{A ESTIMATING AVERAGE EFFECTIVE TAX RATES}

In this section, tax rates on capital, labor, consumption and services are estimated for both the U.S. and Sweden. I follow Mendoza et al. (1994) and relate realized tax rates directly to the relevant macroeconomic variables in the National Accounts. The resulting estimates are called average effective tax rates (AETR) or "implicit rates", and are consistent with the concept of aggregate tax rates at the national level. The tax revenue data is taken from the OECD Revenue Statistics database, which contains information on tax revenues as reported by member countries. Estimates of the values of the associated tax bases come from National Accounts.

\{Table 8 here $\}$ 


\section{A.1 EFFECTIVE TAX RATES ON CONSUMPTION AND SERVICES}

In the U.S., tax rates on services are basically zero. ${ }^{58} \mathrm{I}$ use this as a benchmark and compute the tax rate on consumption goods in the U.S. by deducting household and government spending on services from the tax base. For Sweden, I assume equal tax rates on consumption goods and services. ${ }^{59}$ The AETRs on consumption goods and services are given by ${ }^{60}$

$$
\tau_{u s}^{c}=\left[\frac{5110+5121}{C P+C G-S-5110-5121}\right] \times 100, \quad \tau_{u s}^{s}=0
$$

and

$$
\tau_{s w}^{c}=\tau_{s w}^{s}=\left[\frac{5110+5121}{C P+C G-5110-5121}\right] \times 100
$$

Note that indirect taxes are deducted in the denominator to express the indirect tax rate as a percentage of the pre-tax price.

\section{A.2 EFFECTIVE TAX RATE ON LABOR}

The Mendoza approach to calculate AETRs on factor income is to first calculate AETR on total household income $\tau^{i}$, and then use this estimate to compute labor and capital taxes. Income and labor taxes are given by:

\footnotetext{
${ }^{58}$ Isaacson and Bertoni (2000).

${ }^{59}$ This has been the explicit ambition of the legislator. Formally, the argument is that a uniform VAT on all consumption goods (i.e., including services) will not distort production or consumption in any way. Laws concerning VAT have been revised several times, but the main principle is still a statutory tax rate of 20 percent for both goods and services. See SOU 1997:17.

${ }^{60}$ Equations (16) and (17), differ from their counterparts in Mendoza et al. (1994), in that government wage consumption is not excluded from the consumption tax base since failure to include government wages in the tax base result in AETRs is overstated in countries where these services are publicly provided (such as Sweden) relative to the AETRs in countries where they are privately provided (such as the U.S.). See Carey and Tchilinguirian (2000).
} 


$$
\tau^{i}=\left[\frac{1100}{O S P U E+P E I+W}\right] \times 100 ; \quad \tau^{h}=\left[\frac{\theta^{i} W+2000+3000}{W+2200}\right] \times 100 .
$$

Unfortunately, these estimates (18) overstate the AETRs on capital and labor in countries where social security benefits are subject to high taxation (such as Sweden, Denmark, Finland and the Netherlands). ${ }^{61}$ Direct taxes and social security contributions paid on government benefit payments should therefore be excluded from the tax ratio calculations. This is done by deducting direct taxes on social security benefits (DTB) from the numerator of $\tau^{i}$ in (18), and by deducting social security contributions levied on social security benefits (SSCB) from the numerator of $\tau^{h}$ in (18). ${ }^{62}$ Estimates of DTB and SSCB are found in Adema (2001), but are only available for 1993, 1995 and 1997. In addition, Adema only reports combined estimates of direct taxes and social security contributions on government benefits, implying that these estimates must be divided into direct taxand social security components. I use data from the OECD Taxing Wages database to calculate direct taxes and social security contributions for different households. ${ }^{63}$ The average proportion of each component is then used to allocate Ademas' series to its direct tax- and social security contributions components. I also assume these proportions to have been constant over this time period.

Modified income and labor taxes are then given by

$$
\tau^{i}=\left[\frac{1100-D T B}{O S P U E+P E I+W}\right] \times 100 ; \quad \tau^{h}=\left[\frac{\tau^{i} W+2000+3000-S S C B}{W+2200}\right] \times 100 .
$$

These modifications ensure that two otherwise identical countries with the same net government benefit payments will have the same tax ratios, even if one country does not tax

\footnotetext{
${ }^{61}$ Carey and Tchilinguirian (2000).

${ }^{62}$ See Carey and Rabesona (2002).

${ }^{63}$ For individuals earning 67, 100 and 133 percent of average production wages, respectively.
} 
such payments at all, while the other imposes a very high tax on them. The estimated AETRs are presented in table $9 .^{64}$

\{Table 9 here $\}$

The numbers in parenthesis are the estimates of AETRs without excluding direct taxes and social security contributions paid on government (transfer) payments. The decline in the labor income tax rate is substantial for Sweden (more than 7 percentage points), but is limited for the U.S. (less than half a percentage point).

\section{A.3 SUBSIDIZING DAY CARE}

The government's total cost for day care is computed by multiplying the total cost per child in day care by the total number of children enrolled. The total cost of the subsidy amounts to roughly 8 percent of total household consumption expenditures (excluding services). ${ }^{65} \mathrm{I}$ incorporate this into the model by letting a share of the government's tax revenues finance the subsidy to market work. Specifically, the total cost in the model is $\tau^{n} H w$, which should equal 8 percent of total household consumption expenditures (i.e., $\left.0.08 C\left(1+\tau^{c}\right)\right)$, so the tax $\tau^{n}$, is given by $\tau^{n}=\left[\frac{0.08 C\left(1+\tau^{c}\right)}{H w}\right] \times 100$.

\section{B A higher Frisch elasticity of labor supply}

I here analyze the importance of labor supply elasticity for the results in table $2{ }^{66}$ In the first case, $\mu$ is set to 1 , implying a log function and an average Frisch elasticity of 2.4, which is well above most empirical estimates. The other case considered is to set

\footnotetext{
${ }^{64}$ AETRs on consumption, services and labor are all for the year 2002, except the U.S. labor tax, which is for 2001, due to missing data for 2002. My estimates of this tax rate are very stable from 1997-2001, so this assumption should be rather innocent.

${ }^{65}$ The data on the total subsidy cost is from the Swedish National Agency for Education and the estimate on services is found in the National Accounts.

${ }^{66} \mathrm{I}$ focus on the intertemporal elasticity since the static (i.e. the compensated and uncompensated) elasticities are somewhat more messy to compute in the setting with home production.
} 
$\mu=10$, implying an average elasticity of 0.24 . This value is in line with the estimates for married men. ${ }^{67}$ In all cases, the model is recalibrated to match Swedish hours. The result is presented in table 10 .

\{Table 10 here $\}$

As can be seen in table 10, even though the Frisch elasticity is reduced by a factor of ten, home and market work only differ by roughly one percent between the two extremes. This is first due to the fact that $\mu$ governs the relation between leisure and total working time and it does not directly affect the relation between market work and home production $\left(\frac{h_{n}}{h_{m}}\right.$ is 60 percent in all three cases in table 10). A lower $\mu$ implies that households are more willing to substitute leisure for total working hours. The effect on market hours, however, is smaller than in models without home production, since the increase in total hours is divided by both market work and home production. Second, the recalibration requires the taste parameter for leisure to be high when elasticity is high, which also reduces the response to tax differences. Clearly, a high elasticity of labor supply is not needed to explain the difference in hours worked in a model with home production.

\footnotetext{
${ }^{67}$ Intertemporal responses are greater than compensated responses which, in turn, are greater than uncompensated responses. The elasticity of $0.24(\mu=10)$ is thus an upper bound for the static elasticities. The compensated elasticity in the case with $\mu=10$ is well in line with the studies referred to in Alesina, Glaeser and Sacerdote, 2005.
} 


\section{References}

Adema, W., "Net Social Spending, 2nd edition," OECD Labor Market and Social Policy Occasional Papers No. 52, 2001.

Alesina, A., E., Glaeser and B. Sacerdote, "Work and Leisure in the U.S. and Europe: Why so Different?," in NBER Macroeconomics Annual, eds M. Gertler \& K. Rogoff, (Cambridge MA: The MIT Press, (2005).

Blanchard, O., "The Economic Future of Europe," NBER working paper 10310, 2004.

Browning, M., L. P. Hansen and J.J. Heckman, "Micro Data and General Equilibrium Models," in Taylor, John B and Woodford, Michael eds., Handbook of Macroeconomics, (Amsterdam: North-Holland, 1999, Volume 1A).

Burda, M. C,. D. S. Hamermesh and P. Weil, "The Distribution of Total Work in the EU and US.," IZA Discussion Paper No 2270, August 2006.

Carey, D., and J. Rabesona, "Tax Ratios on Labour and Capital Income and on Consumption," OECD Economic Studies No.35, 2002

Carey, D., and H. Tchilinguirian, "Average Effective Tax Ratios on Capital and Consumption," OECD Economics Department Working Paper No.258, 2000.

Davis, S. J., and M. Henrekson, "Personal Taxes and the Scope for Market activity," mimeo, the University of Chicago, 2002.

De Nardi, M., "Wealth Inequality and Intergenerational Links," Research Department Staff

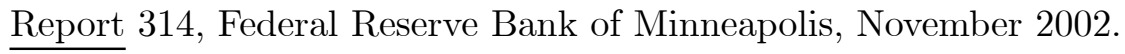

Domeij, D., and P. Klein, "Inequality of Income and Wealth in Sweden," Mimeo, Institute for International Economic Studies, Stockholm University, 1998.

Economic Report of the President, Washington 2004. 
European Economy No 6/2003. Belgium, 2004.

Flodén, M., and Lindé, J., "Idiosyncratic Risk in the U.S. and in Sweden: Is there a Role for Government Insurance?," Review of Economic Dynamics, 4(2), (2001), 406-437.

Freeman R. B., and R. Schettkat, "Marketization of Production and the U.S.-Europe Employment Gap," NBER working paper 8797, 2002.

Giannarelli, L., S. Adelman and S. Schmidt, "Getting Help with Child Care Expenses", The Urban Institute, Occasional Paper Nr.62, 2003.

Greenwood, J., R. Rogerson and R. Wright, "Household Production in Real Business Cycle Theory," in Cooley, Thomas F, ed., Frontiers of Business Cycle Research, (Princeton: Princeton University Press, 1995), 157-174.

Hultkrantz, L., and E. Johansson, "Hemarbetet och BNP," replik i Ekonomisk Debatt, 6 (2003).

Isaacson, G., and D. Bertoni, "A Tax Whose Time has Passed? Problems With State Sales and Use Taxes In An Electronic Commerce Environment," mimeo, 2000.

Jacobsen, J. P., and P. Kooreman, "Timing Constraints and the Allocation of Time: The Effects of Changing Shopping Hours Regulations in the Netherlands," European Economic Review 49, (2005), 9-27.

Juster, T. F., and F. P. Stafford, "The Allocation of Time: Empirical Findings, Behavioral Models, and Problems of Measurements," Journal of Economic Literature, 29 (1991), 471522.

Lindbeck, A, "Work Disincentives in the Welfare State," Nationalökonomische Gesellschaft Lectures 79-80 (Vienna: Manz, 1981).

- _-_- "Tax Effects Versus Budget Effects on Labor Supply," Economic Inquiry, Vol. XX (1982), 473-489. 
McGrattan, E., R. Rogerson and R. Wright, "Household Production and Taxation in the Stochastic Growth Model," Federal Reserve Bank of Minneapolis Staff Report 166, December 1993.

Mendoza, E. G., A. Razin, and L. Tesar, "Effective Tax Rates in Macroeconomics: CrossCountry Estimates of Tax Rates on Factor Incomes and Consumption," Journal of Monetary Economics, 34 (1994), 297-323.

Nickell, S., "Employment and Taxes," CEP Discussion paper No 634, May 2004.

OECD Labor Database, Labor Market Statistics. (On-line data).

OECD Revenue Statistics 2003 (On-line data).

OECD Statistical Database, Annual National Accounts (On-line data).

Prescott, E. C. "Why do Americans Work so Much More than Europeans?," Federal Reserve Bank of Minneapolis Quarterly Review Vol.28 No.1, 2004.

Ragan, K. S., "Fiscal Policy and the Family: Explaining Labor Supply in a Model with Household Production," mimeo, University of Chicago, 2005.

Rogerson, R., "Structural Transformation and the Deterioration of European labor Market Outcomes," NBER working paper 12889, 2007a.

_____. "Taxation and Market Work: Is Scandinavia an Outlier." NBER working paper 12890, 2007b.

Rupert, P., R. Rogerson and R. Wright, "Estimating Substitution Elasticities in Household Production Models," Economic Theory 6 (1995), 179-193.

_- _ _ . "Homework in Labor Economics: Household Production and Intertemporal substitution," Journal of Monetary Economics 46 (2000), 557-579.

Data on Swedish government consumption from Statistics Sweden, at http://www.scb.se. 
Data on Swedish value added taxes and payroll taxespayroll taxes from Skattebetalarnas Förening at: http://www.skattebetalarna.se

Skatter, tjänster och sysselsättning. SOU 1997:17. (Stockholm: Finansdepartementet, 1997).

Skattestatistisk Årsbok 2002, RSV 152, utgåva 5 (Halmstad, 2002).

Tid för Vardagsliv. Kvinnors och mäns tidsanvändning 1990/91 och 2000/2001, Rapport 99, (Örebro, Sweden: Statistiska Centralbyrån, 2003)..

Utgiftsbarometern 2001. (Sweden: Statistiska Centralbyrån, 2002). 


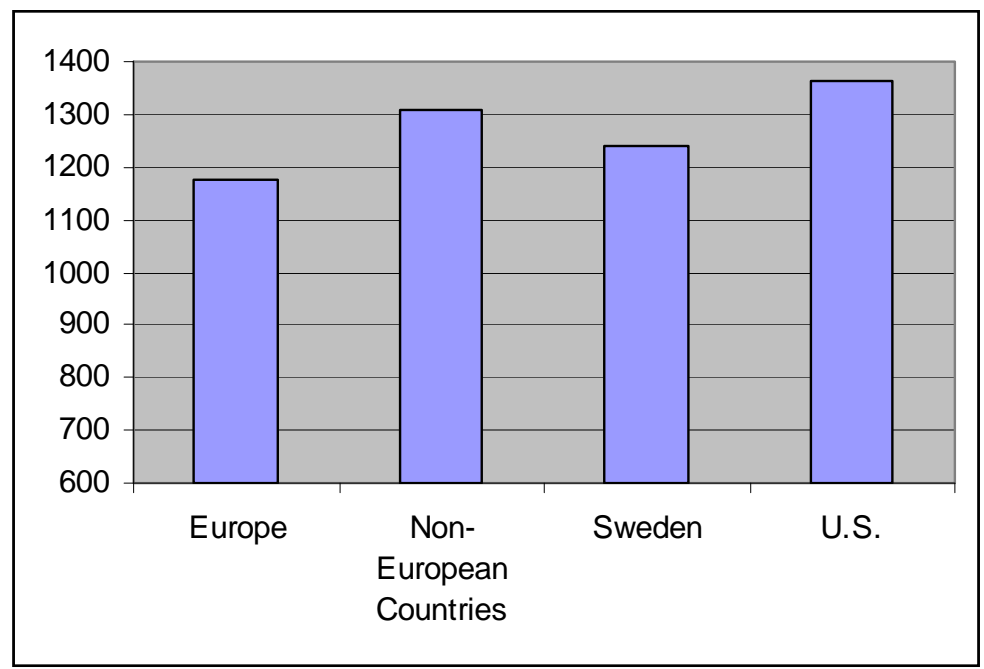

Figure 1: AVERAGE ANNUAL HOURS OF MARKET WORK PER PERSON (20-64) 


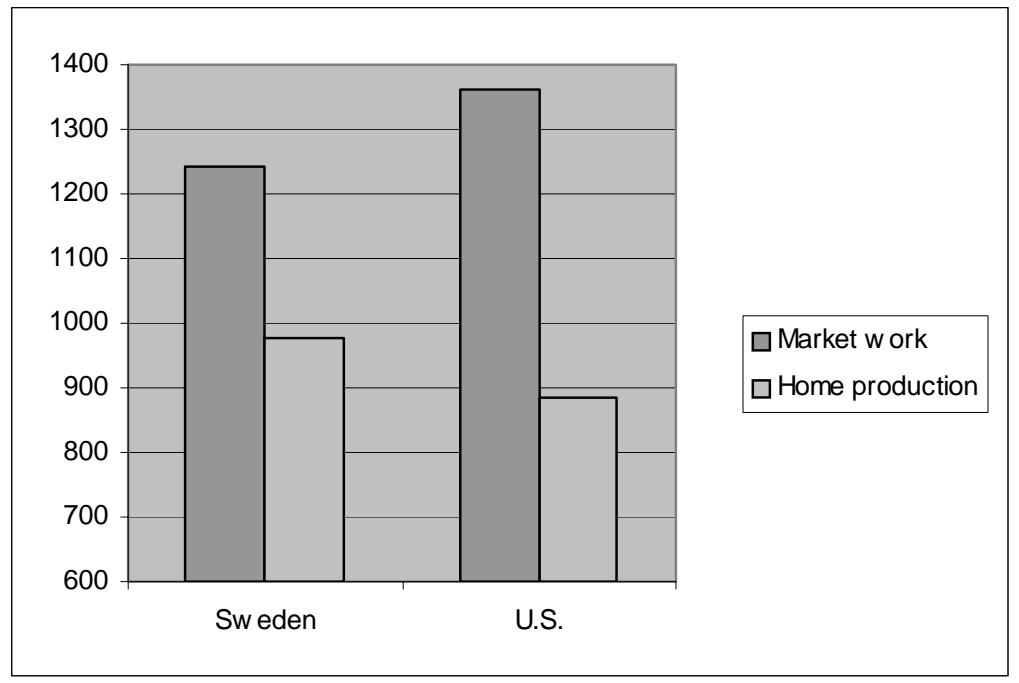

Figure 2: ANNUAL HOURS OF PAID AND UNPAID WORK 


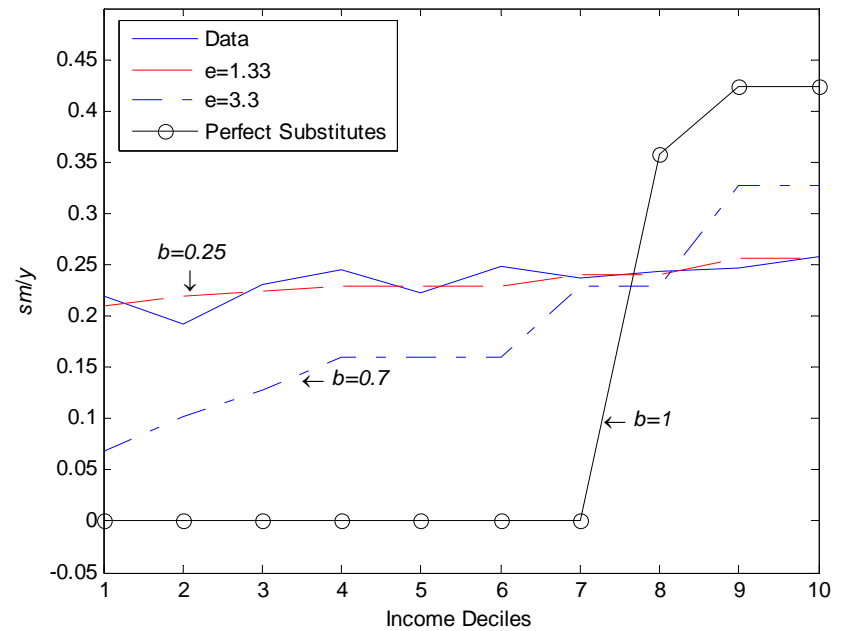

Figure 3: THE DEMAND FOR MARKET SERVICES AS SHARES OF INCOME BY INCOME DECILES 


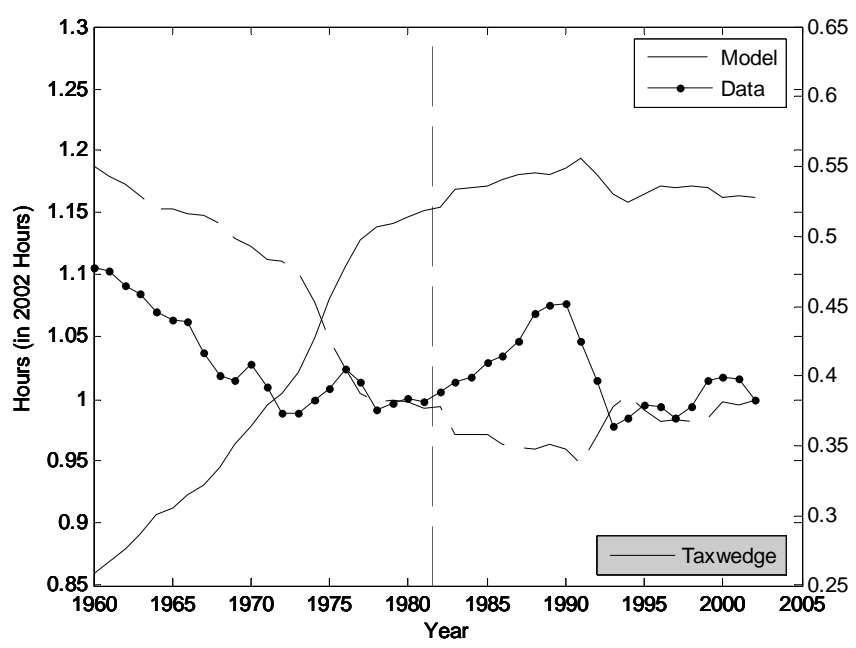

Figure 4: AVERAGE HOURS IN THE MODEL AND THE DATA 
Table 1: ACTUAL HOURS WORKED IN PERCENT

\begin{tabular}{lcc}
\hline \hline & SWEDEN & U.S. \\
\hline MARKET WORK & 23.88 & 26.18 \\
HOME PRODUCTION & 18.93 & 17.15 \\
GDP/CAPITA & 1 & 1.31 \\
\hline
\end{tabular}


Table 2: HOURS WORKED IN THE DATA AND THE MODEL

\begin{tabular}{lcccccc}
\hline \hline & \multicolumn{3}{c}{ DATA } & \multicolumn{3}{c}{ MODEL } \\
& SWEDEN & U.S. & SWEDEN & U.S. \\
& & & & $G>0$ & $G=0$ \\
\hline MARKET WORK & 23.88 & 26.18 & 23.88 & 26.76 & 27.54 \\
HOME PRODUCTION & 18.93 & 17.15 & 18.93 & 16.15 & 16.49 \\
GDP $/$ CAPITA & 1 & 1.31 & 1.00 & 1.08 & 1.15 \\
GDP $/$ CAPITA ADJUSTED & - & - & 1.27 & 1.31 & 1.38 \\
\hline $1.057, \eta=0.5155, a=0.3728, b=0.25$ for $G>0$, and $\varphi=0.589, \eta=0.5675, a=0.4273, b=0.2650$ \\
& for $G=0$
\end{tabular}


Table 3: AGGREGATE VARIABLES

\begin{tabular}{cccc}
\hline & \multicolumn{3}{c}{ U.S./SWE } \\
& $K$ & $C+G$ & $C+G+S M$ \\
\hline$G>0$ & 1.01 & 1.01 & 1.08 \\
$G=0$ & 1.11 & 1.11 & 1.15 \\
\hline
\end{tabular}


Table 4: HOURS BY INCOME IN SWEDEN

\begin{tabular}{lccccc|ccccc}
\hline \hline \multicolumn{1}{c}{ SWEDEN } & \multicolumn{1}{c}{ U.S. } \\
$\frac{h_{t}}{h_{t}+h_{n}}$ & Q1 & Q2 & Q3 & Q4 & Q5 & Q1 & Q2 & Q3 & Q4 & Q5 \\
\hline DATA & 0.51 & 0.53 & 0.55 & 0.58 & 0.62 & 0.50 & 0.57 & 0.62 & 0.64 & 0.72 \\
MODEL $(G>0)$ & 0.52 & 0.57 & 0.58 & 0.59 & 0.55 & 0.56 & 0.62 & 0.64 & 0.65 & 0.66 \\
MODEL $(G=0)$ & 0.44 & 0.55 & 0.58 & 0.61 & 0.62 & 0.50 & 0.62 & 0.65 & 0.68 & 0.70 \\
\hline
\end{tabular}


Table 5: ANALYZING POLICY INSTRUMENTS SEPARATELY

\begin{tabular}{lcccc}
\hline \hline & SWEDEN & U.S. $G$ & U.S. PROD. & U.S. TAXES \\
\hline MARKET WORK & 23.88 & 20.18 & 22.73 & 31.12 \\
HOME PRODUCTION & 18.93 & 20.60 & 20.13 & 13.91 \\
GDP/CAPITA & 1 & .86 & .99 & 1.25 \\
GDP/CAPITA ADJUSTED & 1.2 & 1.16 & 1.28 & 1.45 \\
\hline
\end{tabular}


Table 6: ANALYZING TAXES SEPARATELY

\begin{tabular}{lcccc}
\hline \hline & SWEDEN & U.S. $\tau^{h}$ & U.S. $\tau^{c}$ & U.S. $\tau^{s}$ \\
\hline MARKET WORK & 23.88 & 28.79 & 25.16 & 24.90 \\
HOME PRODUCTION & 18.93 & 15.43 & 18.06 & 18.11 \\
GDP/CAPITA & 1 & 1.18 & 1.05 & 1.03 \\
GDP/CAPITA ADJUSTED & 1.2 & 1.40 & 1.31 & 1.29 \\
\hline
\end{tabular}


Table 7: WELFARE EFFECTS OF U.S. TAXES IN SWEDEN

\begin{tabular}{cccccc}
\hline \hline \multicolumn{5}{c}{ CV BY INCOME QUINTILES } \\
\hline$G>0$ & -6.2 & 1.3 & 4.7 & 7.7 & 11.9 \\
$G=0$ & -1.0 & 2.9 & 4.8 & 6.6 & 9.3 \\
\hline
\end{tabular}


Table 8: VARIABLE NAMES AND SYMBOLS USED

Revenue Statistics:

$1100=$ Taxes on income, profit and capital gains of individuals or households

$2000=$ Total social security contributions

$2200=$ Social security contributions paid by employers

$3000=$ Taxes on payroll and workforce

$5110=$ General taxes on goods and services

$5121=$ Excise taxes

National Accounts:

$\mathrm{CP}=$ Household final consumption expenditure

$\mathrm{CG}=$ Government final consumption expenditure

$\mathrm{S}=$ Household consumption expenditures on services

OSPUE $=$ Households' unincorporated operating surplus

$\mathrm{PEI}=$ Households' property income

$\mathrm{W}=$ Wages and salaries 
Table 9: AETRS IN SWEDEN AND THE U.S. (PERCENT)

\begin{tabular}{ccccc}
\hline \hline & $\tau^{c}$ & $\tau^{s}$ & $\tau^{i}$ & $\tau^{h}$ \\
\hline SWEDEN & 20.00 & 20.00 & $23.15(27.08)$ & $46.01(53.12)$ \\
THE U.S. & 8.05 & 0.00 & $14.81(15.05)$ & $26.79(27.26)$ \\
\hline
\end{tabular}


Table 10: EVALUATING THE IMPORTANCE OF THE FRISCH ELASTICITY

\begin{tabular}{|c|c|c|c|c|}
\hline & \multirow[t]{2}{*}{ SWEDEN } & \multicolumn{3}{|c|}{ U.S. } \\
\hline & & $\frac{\mu=1}{\operatorname{IES}=2.4}$ & $\frac{\mu=5}{\operatorname{IES}=0.48}$ & $\frac{\mu=10}{\mathrm{IES}=0.24}$ \\
\hline MARKET WORK & 23.88 & 27.03 & 26.76 & 26.70 \\
\hline HOME PRODUCTION & 18.93 & 16.44 & 16.25 & 16.22 \\
\hline
\end{tabular}

